\title{
DEMOKRASI PERSPEKTIF HIZBUT TAHRIR VERSUS RELIGIOUS MARDOMSALARI ALA MUSLIM IRAN
}

\author{
Ainur Rofiq al-Amin \\ Institut Agama Islam Negeri Sunan Ampel Surabaya, Indonesia \\ E-mail: ar.alamin1972@gmail.com
}

\begin{abstract}
In general, Muslim responses to democracy are threefold. The first is the Muslim group which accepts without reserve the concept of democracy. This group appreciates the discourse of democracy as such without any criticism. The second is the Muslim group which accepts democracy with criticism. This group tries to elaborate democracy which is in line with culture, tradition and religion in a particular country. This group rejects to be dictated by the Western model of democracy. The third is the Muslim group which rejects democracy. This group regards democracy as the source of evil and crimes. One that belongs to the third group is Hizbut-Tahrir Indonesia (HTI). According to HTI, democracy is evil, incompatible with Islam. For this reason, this articles focuses on, first, the factors which lead HTI to reject democracy; second, the reason or Islamic legal construct developed by HTI to reject democracy; and third, religious mardomsalari (religious democracy) practiced in the Islamic Republic of Iran. This study is a qualitative research based on the study of texts.
\end{abstract}

Keywords: HTI, democracy, Islamic republic of Iran, religious mardomsalari.

\section{Pendahuluan}

Gerakan Hizb al-Tahrîr berdiri di daerah al-Quds Palestina pada tahun 1953. Gerakan ini diprakarsai oleh seorang mantan aktivis alIkhwân al-Muslimûn yang tidak puas dengan organisasi tersebut, yakni Taqîy al-Dîn al-Nabhânî (1914-1977). Gerakan Islamis ini sejak berdiri sering menyebut organisasinya sebagai partai politik yang ingin membedakan dengan gerakan al-Ikhwân al-Muslimûn.

Sebelumnya, gerakan ini pada awal tahun 1953 berupaya mengajukan permohonan izin pendirian partai politik kepada Departemen Dalam Negeri pemerintahan Yordania. Namun 
pemerintahan Yordania menolak berdirinya Hizb al-Tahrîr, bahkan organisasi ini dilarang dan aktivitasnya dianggap ilegal. ${ }^{1}$ Latar belakang berdirinya gerakan ini dapat ditelusuri dari dua aspek: historis dan normatif. Dari aspek historis, Hịb al-Tahrîr melihat kemunduran yang menimpa umat Islam dalam rentang waktu yang panjang. Umat Islam sejak abad ke-19 Masehi berada dalam kemunduran pemikiran dan peradaban. Mereka dijajah dan dikuasai oleh Barat tanpa bisa mengentaskan diri dari absolutisme bangsa Barat. Akhirnya umat Islam sedemikian terjerembab dalam kehidupan sosial, politik, dan ekonomi. Dalam kondisi demikian, banyak kelompok-kelompok Islam berusaha menyelamatkan keterpurukan umat Islam. Hanya saja menurut Hịb al-Tahrî̀, jangankan kelompok-kelompok Islam tersebut berhasil menyelamatkan keterpurukan umat Islam, akan tetapi justru menambah labirin problem umat Islam yang kian rumit. ${ }^{2}$

Sebagai pendiri dan pemimpin pertama Hịb al-Tahrîr, Taqîy alDîn al-Nabhânî melihat setelah era kekhilafahan Turki Ottoman selesai pada tahun 1924, umat Islam mengalami dekadensi di berbagai sektor kehidupan. Lebih dari itu, umat Islam juga direndahkan dan diinjak-injak harga dirinya, serta kemuliannya dihilangkan. Untuk itu, cita-cita yang diinginkan adalah kembali kepada Islam untuk menjadi luhur dan terhormat serta tidak direndahkan lagi. ${ }^{3}$ Akhirnya gerakan ini berdiri untuk menegakkan khilâfah Islam agar umat tidak mengalami kemunduran dan kemerosotan yang menghinakan. ${ }^{4}$

Sementara dari aspek normatif, berdirinya Hịzb al-Tahrî̀ dalam rangka menyambut dan menjawab firman Allah dalam surah Âli Imrân [3]: 104, ${ }^{5}$ di mana, dalam tafsirannya, ayat ini tidak hanya menyuruh sebagian umat Islam agar melakukan dakwah kebaikan dan amar ma'rûf naby munkar. Akan tetapi lebih dari itu, dakwah tersebut harus dalam format jamaah yang terorganisir dalam bentuk partai politik, dan format seperti ini adalah tuntutan atau perintah wajib. ${ }^{6}$

\footnotetext{
${ }^{1}$ Yahya Abdurrahman, "Biografi Singkat Pendiri Hizbut Tahrir Syaikh Taqiyuddin an-Nabhani”, Al-Wa'ie, No. 55 tahun V (Maret 2005), 35-36.

${ }^{2}$ Hịb al-Tahrîr, Mafâhîm Ḥiz̧b al-Taḥrî (Al-Quds: Ḥiẓb al-Tahrîr, 2001), 3; dan Taqî al-Dîn al-Nabhânî, al-Takattul al-Ḥiz̧bî (Al-Quds: Ḥizb al-Tahrîr, 2001), 3.

3 Tim Redaksi Al-Wa'ie, "Meneropong Hizbut Tahrir bagian 1", Al-Wa'ie, No. 77 tahun VII (Januari 2007), 20.

${ }^{4}$ Hịizb al-Tahrîr, Hį̧̣ al-Taḥrîr (Beirut: Dâr al-Ummah, 2010), 5-6.

5 Ibid., 5-6.

${ }^{6}$ Ibid., 6-7.
} 
Dalam analisis peneliti, trigger terpenting yang menginspirasi alNabhânî mendirikan organisasi politik tersebut adalah berdirinya negara Israel pada tahun 1948. Kemudian Israel ini melakukan penjajahan terhadap negara-negara yang ada di sekitarnya, termasuk Palestina yang merupakan tanah kelahirannya. Dengan demikian, kehancuran khilâfah Turki Uthmânî yang diruntuhkan oleh Mustafa Kemal Attaturk pada tahun 1924 kemungkinan bukan inspirasi awal bagi al-Nabhânî untuk mendirikan Hịzb al-Tahrîr. Kalau inspirasi awal, tentu tidak sampai tahun 1953 al-Nabhânî baru mendirikan Hịb al-Tahrîr. Perlu diketahui, al-Nabhânî pada tahun 1932 M telah memperoleh ijazah 'álamîyah (setingkat doktor dari al-Azhar), dan pada tahun itu juga (1932) menjadi guru di Haifa Palestina, serta pada tahun 1938 menjabat di Mahkamah Sharî‘ah Haifa Palestina. ${ }^{8}$ Artinya, dengan rentang waktu yang ada (tahun khilâfah runtuh, penjajahan Israel, dan berdirinya HT), maka faktor penjajahan Israel atas Palestina lebih dekat dan bisa dijadikan analisis atas berdirinya HT. Hampir mirip dengan penjelasan Masdar Hilmy, organisasi transnasional seperti Ḥizb al-Tahrîr lahir di Palestina karena banyaknya solidaritas dunia atas penjajahan oleh Israel. ${ }^{9}$

Tujuan berdirinya Hizb al-Tahrîr adalah untuk melanjutkan kehidupan Islam (istinâf al-ḥayâh al-Islâmîyah) serta mengemban misi dakwah Islam. ${ }^{10}$ Hịb al-Tahrîr menjelaskan bahwa problem besar, urgen, dan mendasar atas umat Islam di dunia sekarang ini hanya dapat diatasi dengan mengembalikan hukum sharî‘ah dengan menegakkan negara kbilâfah. ${ }^{11}$

Setelah meninggalnya al-Nabhânî pada tahun 1977, tampuk kepemimpinan gerakan ini dipegang 'Abd al-Qadîm Zallûm selama 25 tahun (1977-2003). ${ }^{12}$ Setelah Zallûm meninggal, era kepemimpinannya kemudian diganti oleh Atâa Abû Rashṭah (1. 1943) hingga sekarang ini

\footnotetext{
7 Tim Redaksi Al-Wa'ie, "Mengenal Syaikh Taqiyuddin an-Nabhani, Pendiri Hizbut Tahrir", Al-Wa'ie, No. 74 tahun VII (Oktober 2006), 24.

8 Abdurrahman, "Biografi Singkat", 34.

${ }^{9}$ Masdar Hilmy, Islam sebagai Realitas Terkonstruksi (Yogyakarta: Kanisius, 2009), 133.

${ }^{10}$ Ḥizb al-Tahrî̀, Manbaj Hįizb al-Taḥrî fì al-Taghyîr (Beirut: Hịizb al-Tahrîr, 2009), $27-28$.

11 Ibid., 2.

${ }^{12}$ Hizbut Tahrir Indonesia, Manifesto Hizbut Tahrir untuk Indonesia (Jakarta: Hizbut Tahrir Indonesia, 2009), 71-72; dan Tim Redaksi Al-Wa'ie, “Atha Abu ArRasythah, Amir Hizbut Tahrir Saat Ini”, Al-Wa'ie, No. 77 tahun VII (Januari 2007), $25,27$.
} 
(tahun artikel ini diterbitkan). Dia diangkat menjadi pemimpin Hịb al-Tahrîr pada tanggal 13 April 2003 oleh Dewan Mazâlim. Menurut para pengikutnya, 'Atâa' dinilai sebagai pemimpin yang sanggup membawa Hizb al-Tahrîr lebih sukses dan mendunia. ${ }^{13}$

Dalam situs resmi Hizbut Tahrir Indonesa (HTI), Hizbut Tahrir telah berkembang ke seluruh negara Arab di Timur Tengah, termasuk di Afrika seperti negara Mesir, Libya, Sudan dan Aljazair. Demikian juga ke Turki, Inggris, Perancis, Jerman, Austria, Belanda, dan negaranegara Eropa lainnya hingga ke Amerika Serikat, Rusia, Uzbekistan, Tajikistan, Kirgistan, Pakistan, Malaysia, Indonesia, dan Australia. Hizbut Tahrir masuk ke Indonesia pada tahun 1980-an dengan merintis dakwah di kampus-kampus besar di seluruh Indonesia. Pada era 1990-an ide-ide dakwah Hizbut Tahrir merambah ke masyarakat, melalui berbagai aktivitas dakwah di masjid, perkantoran, perusahaan, dan perumahan. ${ }^{14}$ Perlu dicatat, sekalipun dalam penjelasan di atas sepertinya gerakan Islamis ini telah banyak berkembang di berbagai negara, namun pengikutnya tidak terlalu banyak, hanya aspek yang militan sehingga menjadikan mereka pandai memublikasikan diri dalam berbagai forum dan situs.

Khilâfah dan demokrasi menurut HTI adalah binary opposition, bak pasangan yang berlawanan secara diametral. Khilafah adalah model terbaik sistem politik di dunia, serta satu-satunya kekuatan politik yang mampu mengatasi seluruh problem manusia modern di muka bumi. Fahmi Amhar menjelaskan, hanya khilâfah saja yang mampu melawan arogansi Amerika Serikat, ${ }^{15}$ serta membebaskan negeri-negeri Muslim lain yang dijajah Amerika, seperti Irak dan Afganistan. ${ }^{16}$ Khilâfah juga yang mampu menyatukan umat Islam di dunia yang berjumlah kurang lebih 1.4 miliar. $^{17}$ Karena itulah, terwujudnya khilâfah merupakan puncak dari perjuangan Hizbut Tahrir.

\footnotetext{
13 Tim Redaksi Al-Wa'ie, "Atha Abu Ar-Rasythah”, 25 dan 27.

14 Tim Redaksi Hizbut Tahrir Indonesia, "Tentang Kami”, dalam http://hizbuttahrir.or.id/ (8 April 2012).

${ }^{15}$ Fahmi Amhar, “Hanya Khilafah Islam yang Mampu Melawan AS”, Al-Waie, No. 53 tahun V (Januari 2005), 14.

16 Tim Redaksi Al-Wa'ie, "Krisis Palestina dan Relevansi Khilafah", Al-Wa'ie, No.

72 tahun VI (Agustus 2006), 70.

17 Tim Redaksi Al-Wa'ie, "Akhbar Al-Waie", Al-Wa'ie, No. 73 tahun VII (September 2006), 38.
} 


\section{Realitas Demokrasi menurut Hizbut Tahrir Indonesia}

Data dari situs resmi HTI pada tahun 2013 hingga awal 2014, sudah puluhan kali gerakan ini mengritik tajam fenomena buruk yang menurut mereka diakibatkan oleh demokrasi. Kasus yang menghangat pada tahun 2014 yakni tentang pemilu, dapat ditemukan beberapa pernyataan dari anasir-anasir HTI yang memang dalam pengamatan dan pengalaman peneliti, HTI selalu melakukan kritikan tajam terhadap pesta demokrasi tersebut. Gerakan Islamis ini hampir dapat dipastikan tidak akan ikut berkontribusi dalam pemilu, tapi mereka tidak mau disebut menggembosi pemilu.

Rangkaian kritikan HTI terhadap pesta demokrasi dapat dilacak seperti dari pernyataan Adi Victoria. Humas HTI Samarinda ini menegaskan, pemilu 2014 bukanlah perubahan yang hakiki. Perubahan yang diharapkan kelompok HTI bukan hanya adanya perubahan kepemimpinan, namun juga adanya perubahan sistem politik pemerintahan, yakni perubahan menuju khilafah. ${ }^{18}$ Sedang Ketua HTI, Rokhmat S. Labib ketika meyinggung masalah golputyang isinya dianggap sebagai pembelaan diri dari keengganan untuk menyoblos, sekaligus lahan promosi ide anti-demokrasi-, menjelaskan bahwa bukan golput yang membuat orang kafir berkuasa, tetapi karena demokrasi diterapkan di Indonesia, jadi demokrasi harus dicampakkkan. ${ }^{19}$

Selanjutnya pada suatu acara yang juga dimuat di situs HTI, dikabarkan jelang Pemilu 2014 tersebut terdapat sekitar 300 ulama Jatim dan 79 ulama tamu se-Indonesia menggelar mudhâkarah ulama yang hasilnya menyerukan seluruh komponen bangsa untuk menolak demokrasi. ${ }^{20}$ Hal tersebut dengan mudah dibaca sebagai penolakan terhadap pesta demokrasi 2014. Sedang koordinator Lajnah Khusus Intelektual MHTI Jawa Barat, Indira S. Rahmawaty menjelaskan, sistem demokrasi yang telah dijalankan selama puluhan tahun di Indonesia telah nyata gagal membawa kesejahteraan yang hakiki bagi rakyatnya. Baginya, pemilu sebagai bagian dari proses demokrasi

\footnotetext{
18 Adi Victoria, "Perubahan Hakiki Bukan dari Pemilu", dalam http:/ / hizbut-tahrir. or.id /27-03-2013/ (8 April 2013).

${ }^{19}$ Tim Redaksi Hizbut Tahrir Indonesia, "Bukan Golput, tapi Demokrasi yang Beri Peluang Kafir Berkuasa”, dalam http://hizbut-tahrir.or.id/07-04-2012/ (8 April 2013).

20 Tim Redaksi Hizbut Tahrir Indonesia, "Jelang Pemilu Ratusan Ulama Jatim Serukan Tolak Demokrasi”, dalam http://hizbut-tahrir.or.id/09-03-2012/ (18 Maret 2013).
} 
hanya berhasil mengganti rezim penguasa saja, sementara sistemnya tidak berubah, maka perubahan yang hakiki mustahil terwujud. ${ }^{21}$

Tidak hanya masalah pemilu 2014 yang dikritik HTI, bisa ditarik ke belakang pada bulan November 2013 terkait dengan program penyadapan Amerika ke banyak negara juga menjadi kritikan empuk HTI. HTI mengritik Amerika sejatinya hanya mempermainkan konsep liberal dalam demokrasi. Faktanya NSA sebagai gabungan intelijen Amerika malah bersekongkol dengan raksasa teknologi Amerika seperti Microsoft, Google, Verizon, AT \& T dalam hal spionase tersebut. ${ }^{22}$

Dalam konteks Miss World (September 2013), Iffah Ainur Rohmah, Jubir Muslimah HTI, menyatakan kapitalisme dengan demokrasinya menggiring semua orang termasuk para pemimpin yang selama ini dikenal taat beragama untuk menghalalkan yang diharamkan Allah dengan alasan politik dan pariwisata. Sedang jubir HTI menyatakan, masyarakat semakin sadar atas kegagalan negara ini dalam menjaga moralitas bangsa. ${ }^{23}$

Gerakan Islamis ini mengritik perempuan sebagai pihak yang tanpa sadar telah menjadi objek eksploitasi kapitalis untuk meraih keuntungan melalui perhelatan Miss Universe, Miss World dan sejenisnya. Akhirnya kaum perempuan hanya sebagai komoditas dagang dan pemuas nafsu laki-laki semata. Atau sebaliknya sebenarnya mereka sadar telah dijadikan objek komoditas, namun karena merasa diri mereka tidak dirugikan, justru untung, sehingga para perempuan tetap terlibat aktif. ${ }^{24}$

Akhirnya, bagi HTI demokrasi mengorbankan perempuan dengan alasan pertama, demokrasi telah meredusir peran keibuan untuk mengasuh dan mendidik anak-anaknya. Perempuan harus menjadi mesin uang dan penghias kursi jabatan strategis, tanpa pernah mendapatkan penjagaan kehormatan, kesehatan, bahkan keamanan.

21 Tim Redaksi Hizbut Tahrir Indonesia, "Muslimah HTI Serukan Tinggalkan Demokrasi”, dalam http://hizbut-tahrir.or.id/17-03-2013/ (18 Mei 2013).

22 Tim Redaksi Hizbut Tahrir Indonesia, "Demokrasi Liberal Amerika adalah Permainan, Sesungguhnya Amerika adalah Negara Totaliter", dalam http://hizbuttahrir.or.id/12-11-2012/ (13 Januari 2013).

23 Tim Redaksi Hizbut Tahrir Indonesia, "Pernyataan HTI Tolak Penyelenggaraan Miss World 2013 di Indonesia", dalam http://hizbut-tahrir.or.id/30-03-2013/ (26 Juni 2013).

${ }^{24}$ Tim Redaksi Hizbut Tahrir Indonesia, "Penolakan terhadap Ajang Pamer Aurat Miss World Bukti Keimanan Seorang Muslim”, dalam http://hizbut-tahrir.or.id/3101-2013/ (16 Maret 2013). 
Kedua, pendidikan anak tidak maksimal sebagai konsekuensi dari hilangnya peran keibuan. Ketiga, dampak lanjutan dari pemberdayaan perempuan ala demokrasi adalah tingginya angka gugat cerai di kota besar yang disinyalir karena kemandirian istri secara ekonomi dan politik. Keempat, kehancuran masyarakat. Perubahan kaca pandang ibu yang menganggap anak, suami, dan rumah tangga sebagai beban menyebabkan ia enggan menikah atau lebih tenang menjadi single parent. Kelima, makin mengokohkan sistem demokrasi dan ekonomi kapitalis. Banyak perempuan tidak paham bahwa kesetaraan jender dan pemberdayaan perempuan, justru akan melanggengkan sistem demokrasi dan kapitalisme itu sendiri. ${ }^{25}$

Tidak ketinggalan, aktivis Muslimah Hizbut Tahrir Indonesia (MHTI) menandaskan, demokrasi justru merusak kehormatan perempuan. Dengan demokrasi perempuan berhak untuk tidak hamil, tidak menyusui anaknya, meninggalkan bayinya kapan pun mau, tidak perlu taat pada suami, tidak terikat pada pekerjaan rumah tangga, dan bebas berinteraksi dengan laki-laki dan perempuan manapun. ${ }^{26}$

Tidak hanya masalah perempuan, krisis di Mesir antara militer dengan al-Ikhwân al-Muslimûn juga dikaitkan dengan demokrasi. Gerakan HTI menjelaskan pembantaian yang dilakukan militer Mesir sudah seharusnya menyatukan kaum Muslim untuk menegasikan demokrasi. Jalan demokrasi pun tidak bisa dipercaya untuk menghantarkan keberhasilan menegakkan sharî‘ ah Islam. ${ }^{27}$

Menariknya, anggota Lajnah Siyasiyah DPP Hizbut Tahrir Indonesia Iwan Januar menilai kecenderungan aspirasi ekstra parlemen yang semakin tinggi juga dikaitkan dengan rusaknya demokrasi. ${ }^{28}$ Lebih ambigunya lagi, simpatisan HTI, Ahmad Zainuddin, pimpinan pesantren al-Husna Cikampek dan lulusan pesantren al-Anwar Rembang menegaskan, demokrasi adalah buruk tetapi laku dikarenakan negara Indonesia menjadi pelaksana demokrasi. Lanjut Zainuddin, dalam demokrasi, antara pelacur, penjahat, dan orang bodoh tiada beda, sama-sama berhak memilih.

\footnotetext{
25 Tim Redaksi Hizbut Tahrir Indonesia, "Demokrasi Mengorbankan Perempuan", dalam http://hizbut-tahrir.or.id/04-03-2013/ (25 Mei 2013).

${ }^{26}$ Lathifah Musa, "Demokrasi Menghinakan Perempuan", Al-Wa'ie, No. 104 tahun IX (April 2009), 30.

27 Tim Redaksi Hizbut Tahrir Indonesia, "Menolak Jalan Demokrasi", dalam http://hizbut-tahrir.or.id/30-01-2013/ (6 Maret 2013).

28 Tim Redaksi Hizbut Tahrir Indonesia, "Pengusung Demokrasi Takut Ekstra Parlemen Meninggi”, dalam http://hizbut-tahrir.or.id/28-01-2013/ (24 Juni 2013).
} 
Sebaik-baiknya orang yang dipilih dalam sistem demokrasi adalah hasil pilihan orang bodoh, akhirnya pemimpinnya pun tolol. Hal ini berbeda dengan sistem khilâfah, orang bodoh dilarang memilih. Memilih pemimpin dalam Islam dilakukan oleh abl al-hall wa al-'aqd. ${ }^{29}$ Jelas Zainuddin ini telah keliru dalam memahami khilafah HTI yang disamakan dengan sistem politik karya Imam al-Mâwardî dalam alAḥkâm al-Sultânîah.

Pada tanggal 19 Mei 2013, Muslimah Hizbut Tahrir Indonesia (MHTI) Jawa Tengah menggelar Sarasehan Tokoh. Siti Sholihat, anggota MHTI Jawa Tengah, menjelaskan potret buram pendidikan di Indonesia saat ini tidak bisa lepas dari buah sistem demokrasi. Baginya, hanya pendidikan dalam sistem khilâfah saja yang mampu mencetak intelektual yang memiliki derajat mulia dengan keimanan dan keilmuan. ${ }^{30}$ Dalam seminar berjudul Pendidik tak Berakhlak: Buah Penerapan Sistem Kapitalisme-Demokrasi; MHTI menjelasakan, demokrasi sebagai sistem politik yang dipilih negara Indonesia telah menghasilkan para guru yang rendah tanggung jawab untuk mendidik dan memberikan keteladanan. Alih-alih melindungi dari kekerasan seksual dan mencontohkan akhlak mulia, justru guru melakukan perbuatan asusila. ${ }^{31}$

Masih terkait dengan pendidikan, bagi aktivis HTI, demokrasi bukan sistem yang kondusif untuk intelektual. Dalam diskusi intelektual Muslimah yang diselenggarakan Muslimah HTI Indonesia Chapter Kampus DIY di Wisma KAGAMA UGM, Siti Isrina, anggota majelis guru besar UGM menjelaskan bahwa di era demokrasi ini, para intelektualnya tidak punya waktu untuk meng-up date mata kuliah. Sementara untuk mahasiswanya, mereka kehilangan idealism dan tidak bisa membedakan benar dan salahnya ilmu yang sedang dipelajarinya. ${ }^{32}$

29 Tim Redaksi Hizbut Tahrir Indonesia, "Ironi Demokrasi Buruk, tapi Laku", dalam http://hizbut-tahrir.or.id/25-05-2013/ (16 Juli 2013).

30 Tim Redaksi Hizbut Tahrir Indonesia, "Saresehan Intelektual: Ilusi Intelektual Cerdas Bertakwa dalam Sistem Demokrasi", dalam http://hizbut-tahrir.or.id/20-052013/ (5 Juni 2013).

31 Tim Redaksi Hizbut Tahrir Indonesia, "Pendidik tak Berakhlak Buah Penerapan Sistem Kapitalisme Demokrasi”, dalam http://hizbut-tahrir.or.id/24-04-2013/ (6 Mei 2013).

32 Tim Redaksi Hizbut Tahrir Indonesia, "Demokrasi bukan Sistem yang Kondusif”, dalam http://hizbut-tahrir.or.id/27-03-2013/ (24 Juni 2013). 
Sedang terkait dengan pendidikan akhlak anak, demokrasi juga tidak mampu menjaga anak dari pornografi dan seks bebas. Hal ini bisa dideteksi dari beredarnya video mesum artis, juga semakin banyak anak menonton video porno sebagaimana penelitian komnas anak, $97 \%$ anak SD pernah nonton pornografi. Demikian pula survei Komisi Perlindungan Anak Indonesia (KPAI) pada Mei 2010 menyebutkan 97\% anak SMP dan SMA pernah mengakses situs porno di internet. ${ }^{33}$ Bagi MHTI, fakta-fakta di atas menunjukkan upaya pemerintah tidak efektif dalam menanggulangi pornografi, sekalipun sudah dibuat KUHP, Undang-undang Pornografi, Undangundang Perlindungan Anak, dan Undang-undang Informasi dan Transaksi Elektronika. Kesemuanya itu merupakan konsekuensi logis diterapkannya sistem demokrasi yang berpilar pada kebebasan termasuk dalam masalah seks. ${ }^{34}$ Karena demokrasi inilah pornografi dan pornoaksi menjadi legal di tanah air.

Tidak hanya masalah pendidikan dan akhlak anak, terkait dengan politik praktis, HTI menyoroti negeri ini sedang dilanda euforia demokrasi. Selama tahun 2013, hampir dua hari sekali diselenggarakan pemilukada. Euforia demokrasi itu membius rakyat dan membisikkan mimpi-mimpi keadilan dan kemakmuran. Namun menurut HTI, layaknya obat bius, begitu umat kembali sadar, mereka paham bahwa demokrasi bukan solusi, demokrasi merupakan sistem gagal dan merusak yang sejak awal tidak dibutuhkan umat Islam. ${ }^{35}$ Karena jengkelnya, Ketua DPD II Barito Selatan Muhammad Bakrie mengritik demokrasi hanya terbukti menciptakan pemerintahan konyol. Artinya, dua tahun pertama untuk kembalikan modal, satu tahun untuk mengabdi, serta dua tahun sisanya untuk persiapan maju dalam pilkada berikutnya. ${ }^{36}$ Walhasil, demokrasi dianggap sebagai biang korupsi dan kolusi. Tidak aneh jika lembaga antikorupsi kebanjiran kasus setiap menjelang pemilu. Menurut Wakil Ketua KPK Bambang Widjojanto, laporan pengaduan masyarakat terkait dugaan korupsi menjelang Pemilu 2014 ke KPK meningkat. ${ }^{37}$

\footnotetext{
33 Muslimah HTI, Kelemahan Sistem Demokrasi dalam Melindungi Anak dari Pornografi dan Seks Bebas (Jakarta: Muslimah HTI, 2010), 2-5.

${ }^{34}$ Ibid., 6, 15, 16, dan 17.

35 Tim Redaksi Hizbut Tahrir Indonesia, "Demokrasi Sistem Gagal dan Merusak", dalam http://hizbut-tahrir.or.id/15-05-2013/ (25 Mei 2013).

36 Tim Redaksi Hizbut Tahrir Indonesia, "Demokrasi Ciptakan Pemerintah Sableng”, dalam http://hizbut-tahrir.or.id/13-05-2013/ (16 Juni 2013).

37 Tim Redaksi, "Demokrasi Sistem Gagal” (25 Mei 2013).
} 
Akhirnya menurut ketua Hizbut Tahrir Indonesia (HTI) Jawa Timur, Harun Musa saat berpidato di Stadion 10 November Surabaya mengungkapkan bahwa demokrasi menjadi biang kesengsaraan rakyat. Demokrasi merupakan biang neokolonialisme, yang menyebabkan umat Islam dijajah oleh asing. ${ }^{38}$ Dengan lebih terperinci, HTI menyampaikan bahwa demokrasi dijadikan alat penjajahan Barat atas dunia terutama negeri kaum Muslimin. Demokrasi dijadikan dalih untuk langsung melakukan intervensi dan invasi atas berbagai negeri di dunia seperti yang terjadi di Panama, Haiti, dan Irak. Demokrasi pun dijadikan jalan untuk memaksakan UU yang menjamin aliran kekayaan ke Barat dan penguasaan berbagai kekayaan dan sumber daya alam oleh para kapitalis asing. Dengan mekanisme demokrasi pula penguasaan atas kekayaan alam oleh asing bisa dilegalkan dan dijamin. ${ }^{39}$ Inilah yang akhirnya disimpulkan para tokoh HTI seperti Fahmi Amhar dan Hafidz Abdurrahman (Pimpinan Lajnah Tsaqofiyah DPP HTI) bahwa Produk Undang-undang dalam sistem demokrasi adalah penuh kerusakan. ${ }^{40}$

Terkait dengan hukum dan keadilan, Abdullah Zaid, mempertanyakan bahwa demokrasi mampu memberikan rasa keadilan dan persamaan hukum bagi seluruh warga negara. Menurutnya, hukum di negeri ini hanya tajam ke bawah, namun tumpul ke atas. Sebut saja kasus-kasus besar seperti Bank Century yang hingga kini penuh misteri. Ada juga kasus lumpur Lapindo di Porong, Sidoarjo. ${ }^{41}$

Sedang terkait dengan kemiskinan dan kesejahteraan, M. Syaroni, jubir HTI Malang menandaskan selain menjadi biang korupsi, demokrasi juga menjadi biang kemiskinan. 76 juta orang Indonesia antri raskin, 86 juta orang antri jamkesda, dan 40 juta angkatan kerja termasuk pengangguran. Ironisnya proses demokrasi berbiaya tinggi dibiayai oleh rakyat. Dari 495 kabupaten kota dan 33 propinsi dana

\footnotetext{
38 Tim Redaksi Hizbut Tahrir Indonesia, "HTI Ajak Warga Jatim Tinggalkan Demokrasi", dalam http://hizbut-tahrir.or.id/26-05-2013/ (24 Juni 2013). Hizbut Tahrir mengatakan, demokasi digunakan Barat untuk perang budaya dengan negeri Muslim yang hal ini telah disepakati pada muktamar di Berlin pada akhir abad ke delapan belas. Hizbut Tahrir, Afkâr Siyâasîyah (Beirut: Dâr al-Ummah, 1994), 135.

39 Tim Redaksi, "Demokrasi Sistem Gagal” (25 Mei 2013).

40 Tim Redaksi Hizbut Tahrir Indonesia, "Foto: Kerusakan Produk UU dalam Sistem Demokrasi”, dalam http://hizbut-tahrir.or.id/27-04-2013/ (16 Mei 2013).

41 Tim Redaksi Hizbut Tahrir Indonesia, "The End of Democracy", dalam http://hizbut-tahrir.or.id/07-05-2013/ (24 Juni 2013).
} 
untuk pilkada tiap daerahnya menelan dana $40 \mathrm{M}$. Alih-alih untuk kesejahteraan, aset tambang pun justru diserahkan kepada asing. ${ }^{42}$

Lebih jauh dengan mengutip Vilfredo Pareto, Gatano Mosca, dan Robert Michels, demokrasi sebagai topeng yang melindungi tirani minoritas atas mayoritas. Dalam praktiknya yang berkuasa adalah kelompok kecil. Khusus di Indonesia, kenyataannya yang senantiasa diuntungkan adalah kelompok non-Muslim, karena kekuasaan atau modal dimiliki oleh kelompok minoritas mereka. ${ }^{43}$

Hal yang masygul, jubir HTI Ismail Yusanto mengatakan bahwa demokrasi adalah biang kerok terorisme. Karena salah satu prinsip dari demokrasi adalah kebebasan kepemilikan. Artinya, siapa saja boleh memiliki apa saja selama bisa meraihnya tanpa mengenal halalharam. Untuk memiliki uang, Amerika menjual senjata. Untuk meningkatkan penjualan senjatanya maka Amerika akan menciptakan konflik seperti di Irak dan Afghanistan. ${ }^{44}$

Sementara itu, ketua PP Muhammadiyah Haedar Nashir mengritik faksi Islam sharî'at yang mengidap bypocracy in democracy, kemunafikan terhadap demokrasi. Di satu sisi secara tegas menolak demokrasi, tetapi menikmati kehidupan di bawah alam demokrasi. Muhammad Ismail Yusanto menjawab, semua rakyat Indonesia tanpa kecuali, termasuk HTI memang hidup di negara yang menerapkan demokrasi. Akan tetapi Ismail menandaskan, andai disuruh memilih antara hidup di bawah sistem demokrasi dengan hidup di bawah sistem Islam, pasti mayoritas rakyat memilih lebih baik hidup di bawah sistem Islam. ${ }^{45}$ Untuk menambahi bobot argumen di atas, Titok Priastomo sang aktivis HTI, balik bertanya, apakah jika kita dibiarkan hidup dalam sistem demokrasi berarti tidak boleh menentang sistem itu? Jika demikian, apakah jika kita dibiarkan hidup dalam sebuah sistem monarki, feodal, maupun sistem kolonial, lantas kita tidak boleh

Tim Redaksi Hizbut Tahrir Indonesia, "Pengajian Masjid ar-Ridlo Pertegas Demokrasi Biang Korupsi”, dalam http://hizbut-tahrir.or.id/06-04-2013/ (6 Mei 2013).

43 Gus Uwik, "Demokrasi dan Kebohongan Publik", Al-Wa'ie, No. 21 tahun II (Mei 2002), 31.

44 Tim Redaksi Hizbut Tahrir Indonesia, "Demokrasi Biang Kerok Terorisme", dalam http://hizbut-tahrir.or.id/30-01-2013/ (24 Mei 2013).

45 Tim Redaksi Hizbut Tahrir Indonesia, "Yang Menolak Syariah Islam Justru Mengidap Hipocracy Democracy”, dalam http://hizbut-tahrir.or.id/21-07-2013/ (5 Agustus 2013). 
menentang sistem itu? ${ }^{46}$ Lebih dari itu, Ismail Yusanto balik mengritik, yang lebih mengkhawatirkan adalah hipocracy Muslim. Satu sisi ia menikmati diri sebagai seorang Muslim, tapi menolak sharî‘at, inilah Muslim hipokrit. ${ }^{47}$

Walhasil, HTI menyimpulkan, untuk urusan dunia, siapapun yang berdemokrasi akan menjadi buruk. Muhammad Ismail Yusanto menegaskan bahwa di dalam sistem yang buruk, yaitu demokrasi, siapapun akan cenderung menjadi buruk. ${ }^{48}$ Dalam diskusi bertema "Political Outlook 2014: Indonesia di Bawah Demokrasi serta Peluang dan Tantangan Perjuangan Penegakan Khilafah" Ismail Yusanto kembali meyakinkan, hanya dengan mengubah sistem demokrasi menjadi sistem Khilafah sajalah kerusakan akan berakhir. ${ }^{49}$ Sedang untuk urusan akhirat, demokrasi adalah jalan lempang menuju siksa Tuhan, neraka. Rokhmat S. Labib sang Ketua HTI dan penulis buku Tafsir $A l-W$ a'ie pada acara Halaqah Islam dan Peradaban (HIP) Jatim Edisi 25 di Asrama Haji Sukolilo Surabaya menyatakan kalau partai politik mengajak berdemokrasi sama saja dengan mengajak pada pintu neraka Jahanam. ${ }^{50}$

Atas semua paparan fakta akibat demokrasi yang dikemukan HTI di atas, tentu masih debatable. Tanpa harus membela demokrasi matimatian, maupun harus menegasinya secara mentah-mentah, dengan bersikap adil bisa dipahami banyak faktor yang menjadikan umat dan rakyat seperti apa yang digambarkan HTI di atas.

\section{Akar Penolakan Hizbut Tahrir Indonesia terhadap Demokrasi}

Bagi HTI, kebanyakan orang melihat demokrasi disederhanakan sebagai pemilu. Karena itu, demokrasi dianggap sejalan dengan Islam. Namun demokrasi yang hakiki itu bukan hanya pemilu atau pemilihan penguasa. Demokrasi yang hakiki memiliki dua pilar. Pilar pertama, kedaulatan rakyat. Artinya rakyat yang berhak membuat hukum dan

\footnotetext{
46 Tim Redaksi Hizbut Tahrir Indonesia, "Haruskah HTI Berterima Kasih kepada Demokrasi”, dalam http:/ hizbut-tahrir.or.id/04-08-2011/ (31 Juni 2013).

${ }^{47}$ Tim Redaksi, "Yang Menolak Syariah" (5 Agustus 2013).

48 Muhammad Ismail Yusanto, "Dalam Demokrasi, Siapapun Cenderung Jadi Buruk", dalam http://hizbut-tahrir.or.id/27-02-2013/ (24 Mei 2013).

49 Tim Redaksi Hizbut Tahrir Indonesia, "Political Outlook 2014: Selama Masih Demokrasi, 2014 Tetap Krisis!”, dalam http://hizbut-tahrir.or.id/19-01-2013/ (18 Maret 2013).

50 Tim Redaksi Hizbut Tahrir Indonesia, "Rokhmat S. Labib: Mengajak pada Demokrasi Sama dengan Mengajak pada Jahannam", dalam http://hizbuttahrir.or.id/26-02-2013/ (5 Maret 2013).
} 
undang-undang yang digunakan negara dan pemerintah untuk mengurus rakyat. Pilar kedua, rakyat pemilik dan sumber kekuasaan. Yakni, rakyatlah yang memiliki hak memilih penguasa, memonitor dan mengoreksinya dan memberhentikannya. ${ }^{51}$ Dalam posisi demikian, menurut HTI demokrasi melalui wakil-wakilnya di legislatif telah bertindak sebagai tuhan. ${ }^{52}$

Pemimpin tertinggi Hizbut Tahrir saat ini, 'Ața' b. Khalîl Abû alRashțah menjelaskan bahwa demokrasi berarti kedaulatan rakyat, dan itu adalah menetapkan sharî‘ at selain Allah. Artinya menghalalkan dan mengharamkan selain yang ditentukan Allah swt. ${ }^{53}$ Jadi demokrasi merupakan sistem kufur, sebab menjadikan penetapan sharî́at milik manusia dan bukan milik Tuhannya manusia. ${ }^{54}$

Kalau pemimpin tertinggi Hizbut Tahrir di atas mengatakan bahwa demokrasi merupakan sistem kufur, HTI menambahi selain sebagai sistem yang kufur, demokrasi juga bersifat destruktif. Karena demokrasi memuat ide liberalisme yang salah satunya adalah kebebasan beragama. Ide ini sangat membahayakan umat karena akan merusak aqidah Islam. Berdasarkan prinsip ini, agama seolah menjadi permainan, aliran sesat marak, murtad atau keluar dari agama Islam dianggap hal yang wajar. ${ }^{55}$

Jika ditelusuri dari buku-buku yang dikeluarkan oleh Hizbut Tahrir, terdapat kitab yang berjudul al-Dimuqratîyah Nizâam al-Kufr. Yaḥrum Akhdhubâ aw Tatbîquhâ aw al-Da'wah Ilayhâ. Kitab babon untuk menghancurkan dan melumat demokrasi ini walaupun bukan mutabannat, ${ }^{56}$ namun menjadi rujukan penting bagi para aktivisnya. ${ }^{57}$

51 Tim Redaksi Hizbut Tahrir Indonesia, "Demokrasi Bertentangan dengan Islam, Harus Dicampakkan!”, dalam http://hizbut-tahrir.or.id/24-05-2013/ (29 Mei 2013).

52 Hizbut Tahrir Indonesia, Manifesto Hiøut Tabrir, 16.

53 Tim Redaksi Hizbut Tahrir Indonesia, "Jawab Soal tentang Demokrasi”, dalam http:/ hizbut-tahrir.or.id/08-06-2013/ (5 Juli 2013).

54 Ibid.

55 Tim Redaksi Hizbut Tahrir Indonesia, "Demokrasi dan Nasionalisme Kufur dan Beracun”, dalam http://hizbut-tahrir.or.id/09-02-2013/ (6 Maret 2013).

${ }^{56}$ Kitab-kitab mutabannât Hịb al-Tahrîr seperti yang tercantum dalam kitab karya Ḥizb al-Tahrîr yang berjudul Hį̧̣ al-Tạ̣rîr (Al-Ta'rîf) (Beirut: Dâr al-Ummah, 2010), 31-32.

57 Buku-buku yang dikeluarkan oleh Hịizbut Tahrîr terdapat buku yang disebut dengan mutabannât dan tidak mutabannât. Dalam buku mutabannât ada yang cetakan mu'tamad. Mutabannât adalah buku resmi yang harus dijadikan pegangan oleh para pengikut Hịizb al-Taḥrîr. Sedang buku mu'tamad adalah buku mutabannât yang sudah 
Dalam kitab ini dijelaskan inti penolakan terhadap demokrasi karena lima alasan, antara lain: pertama, demokrasi adalah ciptaan akal manusia yang sama sekali tidak ada kaitannya dengan wahyu dan agama samawi. Kedua, demokrasi muncul dari ideologi sekularisme berupa pemisahan agama dari kehidupan yang pada gilirannya pemisahan agama dari negara. Ketiga, demokrasi berpijak dari kedaulatan di tangan rakyat, dan rakyat sumber kekuasaan. Keempat, demokrasi berpijak kepada hukum mayoritas. Kelima, demokrasi mengembangkan ide kebebasan. ${ }^{58}$

Untuk poin kelima tentang kebebasan, Zallûm memerinci ide-ide kebebasan yang dikembangkan demokrasi, pertama adalah kebebasan berideologi atau beraqidah. Ide ini menegaskan bahwa manusia bebas berkeyakinan apapun yang dikehendakinya. Manusia juga bebas memeluk agama tanpa ada tekanan dan paksaan. Demikian juga manusia bebas mengonversi agama baru sehingga seorang Muslim boleh berpindah ke agama Naṣrani atau Yahudi. Padahal, menurut Zallûm, Islam mengharamkan umatnya meninggalkan aqidah Islam. Apabila ada yang meninggalkan agama Islam, dia harus dibunuh. ${ }^{59}$

Ide kebebasan yang kedua menurut Zallûm adalah demokrasi mengumandangkan asas kebebasan berpendapat. Dalam demokrasi adanya kebolehan untuk menyatakan segala pendapatnya dengan berbagai cara tanpa ada yang bisa menghalanginya selama tidak melanggar kebebasan orang lain. Sedang Islam menurut Zallûm berbeda dengan konsep demokrasi. Islam menyuruh umatnya untuk berpegang teguh dalam seluruh ucapan dan perbuatannya dengan hukum Islam, sehingga orang Muslim tidak boleh mengeluarkan pendapat yang bertentangan dengan Islam. ${ }^{60}$

Khilâfah magąine menjelaskan, realitas kebebasan berpendapat masyarakat Barat cuma mitos belaka. Faktanya mempertanyakan tentang keabsahan holocaust bisa berujung pada penjara yang sangat lama. Mencemarkan nama baik di sana dituntut di pengadilan. ${ }^{61}$

diperiksa kembali oleh Hịb al-Tahrîr. Lihat Umi Chaidaroh, "Fikih Perempuan Ḥizb al-Tahrîr"” (Disertasi--IAIN Sunan Ampel, Surabaya, 2011), 21.

58 'Abd al-Qadîm Zallûm, Al-Dimuqrâtîyah Niz̧âm al-Kufr: Yạ̣rum Akbdhubâ aw Tatbîquhâ aw al-Da'wah Ilayhâ (t.t.: Hizb al-Tahrî̀, t.th.), 4.

59 Ibid., 19.

${ }^{60}$ Ibid., 20.

${ }^{61}$ Editor K-Mag, "Menggugat Mitos Kebebasan Berbicara", Khilafah Magazine, No. 7 tahun I (April 2006), 9. 
Beberapa tahun yang lalu, pengadilan Belanda menjatuhkan hukuman denda sebesar 2.500 euro atau 3.200 dolar AS kepada sekelompok Muslim di negaranya karena telah membuat dan memublikasikan kartun holocaust. Poinnya, kartun tersebut mempertanyakan bagaimana bisa sebanyak enam juta orang Yahudi dibunuh pada masa holocaust. Muslim si pembuat kartun itu sebenarnya tidak ingin menyerang tragedi holocaust. Mereka hanya ingin menunjukkan standar ganda kebebasan berbicara yang kerap diterapkan di Belanda dan negara Eropa lainnya. Kartun itu muncul setelah surat kabar Denmark menerbitkan kartun Nabi Muhammad yang memicu protes dari mayoritas umat Islam. ${ }^{62}$

Berbeda penyikapannya sewaktu isu karikatur Nabi Muhammad menyeruak di Denmark, perdana menteri Denmark mengatakan pemerintahan tidak dapat mengintervensi media. Padahal pada pasal 140 kitab undang-undang hukum pidana Denmark mengatakan, "Barangsiapa di depan umum melecehkan atau menghina suatu dogma dan kepercayaan sekelompok orang yang tinggal di negeri ini, maka dia dapat dikenakan hukuman penjara sekurang-kurangnya empat bulan, atau dalam situasi tertentu dikenakan denda."

Selanjutnya ide kebebasan yang ketiga adalah kebebasan kepemilikan. Zallûm menjelaskan bahwa ide ini merupakan konsep yang dihasilkan ideologi kapitalisme dalam ekonomi. Konsep ini menandaskan, manusia bebas memperoleh, mengembangkan, dan mendistribusikan harta benda dengan beragam cara dan sarana, mulai dari penjajahan, riba maupun menimbun. Sedang Islam melarang penjajahan, penimbunan dan pengembangan harta melalui riba. ${ }^{64}$

Lebih jauh kebebasan kepemilikan (freedom of ownership) ini memberikan hak kepada siapapun yang memiliki modal untuk mengembangkan harta dengan cara apapun tanpa peduli halal dan haram termasuk memiliki aset kepemilikan umum yang merupakan milik rakyat seperti air, listrik, atau tambang-tambang yang jumlahnya melimpah. Atas dasar kebebasan pemilikan inilah kekayaan alam negeri-negeri Islam, termasuk Indonesia, dijarah dan dirampok. Perampokan ini dikemas dengan istilah-istilah manis yang menipu

62 Tim Redaksi Hizbut Tahrir Indonesia, "Bukti Standar Ganda, Muslim Belanda Didenda Karena Buat Kartun Holocaust", dalam http://hizbut-tahrir.or.id/21-082010/ (6 November 2012).

63 Editor K-Mag, "Pernyataan Dusta Mengatasnamakan Kebebasan", Khilafah Magarine, No. 7 tahun I (April 2006), 12.

${ }^{64}$ Zallûm, Al-Dîmuqrâtîyah, 20. 
seperti kebebasan perdagangan, pasar bebas, investasi asing, privatisasi, bantuan luar negeri dan lain-lain. ${ }^{65}$

Unsur kebebasan yang keempat menurut Zallum adalah kebebasan individu. Dalam ide ini, seseorang bebas bertingkah laku tanpa memperhatikan norma akhlak, dan kemanusiaan. Atas nama kebebasan, mereka bebas menghancurkan institusi keluarga dengan membentuk institusi tanpa ikatan perkawinan. Mereka zina, berjudi, minum khamr maupun telanjang, homoseksual, lesbian, tanpa boleh ada yang melarang. Adapun Islam melarang hal tersebut, sebab seorang Muslim harus terikat dengan perintah dan larangan dari Allah dalam setiap perbuatan dan aktivitasnya. ${ }^{66}$

Selanjutnya, adakah kaitan antara syura dan demokrasi? Khilafah Magazine menjelaskan, "Democracy seems to have come to mean all things to all men. It has come to be seen as a term of approval for anythings good. Consequently many Muslims have sought to equate the Islamic principle of shura, i.e; consultation, with democracy." ${ }^{67}$ Arti bebasnya adalah demokrasi begitu datang seolah-olah sebagai sesuatu yang sangat berarti bagi semua manusia. Kehadiran demokrasi tampaknya melegalisir segala sesuatu yang baik/bermanfaat bagi manusia. Sebagai akibatnya banyak dari kalangan Muslim mencari titik temu antara demokrasi dengan prinsip shûrâ dalam Islam yakni: musyawarah disamakan dengan demokrasi. Aktivis HTI, Yahya Abdurrahman menandaskan, shûrâ tidak bisa disamakan dengan demokrasi. Sebaliknya, demokrasi seutuhnya tidak sesuai dengan Islam dan tidak diakui oleh Islam. ${ }^{68}$

Shûrâ artinya meminta pendapat (talab al-ra'y), sedangkan demokrasi adalah pandangan hidup dan kumpulan ketentuan untuk seluruh konstitusi, undang-undang, dan sistem pemerintahan. ${ }^{69}$ Shûrâ hanya dilakukan sesama Muslim dengan berpegang kepada sharî‘ah, sedangkan demokrasi yang mengandalkan suara mayoritas tentu

\footnotetext{
${ }^{65}$ Tim Redaksi, "Demokrasi dan Nasionalisme" (6 Maret 2013).

66 Zallûm, Al-Dîmuqrâtîyah, 21.

67 Khilafah Magazine Supplement, International Muslim Khilafah, London, Inggris, Agustus 1994.

68 Tim Redaksi Hizbut Tahrir Indonesia, "Syura: Demokrasi Tidak Sama dengan Islam", dalam http:/ / hizbut-tahrir.or.id/04-03-2013/ (6 Mei 2013).

${ }^{69}$ Farid Wadjdi, "Demokrasi Sistem Kufur", Al-Wa'ie, No. 104 tahun IX (April 2009), 4.
} 
konsekuensinya apabila mayoritas menginginkan sesuatu, walau itu bertentangan dengan sharî́,ah tetap harus dilakukan. ${ }^{70}$

Lebih jauh Yahya Abdurrahman menguraikan: pertama, dalam masalah hukum sharî́ah, termasuk di dalamnya definisi shar $\hat{\imath}$, shârâ boleh dilakukan. Hanya saja, karena hukum shari`‘ah dasarnya adalah dalil sharî‘ah, maka yang menentukan keputusan dalam hal ini adalah faktor kekuatan dalil, bukan yang lain. Jika dalilnya qat tidak perlu dibicarakan lagi. Sebaliknya, jika dalilnya z̧ann $\hat{\imath}$ (tidak pasti), maka keputusannya bergantung pada yang paling baik (absan) yang didefinisikan oleh Ibn 'Abbâs sebagai aqwâ al-dalîl (paling kuat dalilnya) dan abyan al-fahm (paling jelas pemahamannya). Kedua, dalam masalah definisi non-sharì dan masalah sains-teknologi, keputusan ditentukan oleh pendapat yang benar dengan mengacu kepada ahlinya. Keputusan dalam masalah ini tidak dikembalikan pada pendapat mayoritas. Ketiga, dalam perkara yang menunjukkan pada pelaksanaan suatu aktivitas, keputusan dikembalikan pada pendapat mayoritas. Hal ini sesuai dengan praktik Rasul dalam shûrâ saat Perang Uhud. Shûrâ tidak dilakukan dalam menentukan hukum berperang, juga bukan dalam masalah strategi perang, tetapi dalam hal bagaimana melaksanakan perang, yakni bagaimana menghadapi serangan musuh, apakah dilakukan di luar kota Madinah atau di dalam kota. Beliau dan para sahabat senior cenderung untuk melakukannya di dalam kota, sebaliknya mayoritas menghendaki dilakukannya di luar kota. Lalu Rasul mengeluarkan keputusan sesuai dengan pendapat mayoritas. Pendapat para sahabat senior yang notabene lebih ahli dalam strategi perang tidak beliau ambil, karena memang masalahnya bukan masalah strategi perang, tetapi bagaimana melaksanakan aktivitas yang akan dilaksanakan secara bersama-sama oleh umat. ${ }^{71}$ Selain penjelasan di atas, hukum shûrâ dalam Islam bukan merupakan wajib, tapi mandûb saja. Shûrâ juga hanya dilakukan terhadap sesuatu yang tidak ada naṣs atau ketentuannya di dalam al-Qur'ân dan Sunnah. ${ }^{72}$

Itulah konsep, batasan atau definisi dan uraian yang dibuat dan dikurung oleh HTI terkait dengan demokrasi yang pada akhirnya berbuah penolakan. Bila dirunut, latar belakang penolakan demokrasi

\footnotetext{
${ }^{70}$ Rokhmat S. Labib, "Syura Bukan Demokrasi”, Al-Wa'ie, No. 104 tahun IX (April 2009), 45-46.

71 Tim Redaksi, "Syura" (6 Mei 2013).

${ }^{72}$ Maḥmûd 'Abd al-Majîd al-Khâlidî, Qawâid Nizâam al-Hukm fî al-Islâm (Beirut: Dâr al-Buhûth al-'Ilmîyah, 1980), 152.
} 
oleh HTI disebabkan cara memahami bahasa. Bahasa bagi HTI tidak bisa diijtihadi, tapi harus tawqîfî, yakni ikut pada pakem yang telah ditentukan peletak bahasa atau kaum itu sendiri. Taqîy al-Dîn Al Nabhânî menegaskan "La mahala li al-'aql fi al-lughah, bal tatawaqqaf ma'rifatuhâ 'ala al-naql 'an al-wâdị"' (tiada tempat (berijtihad) bagi akal dalam masalah bahasa, akan tetapi mengetahui bahasa itu tidak lain adalah dengan mengikuti apa yang dikatakan oleh peletak bahasa itu). ${ }^{73}$

Memang pada umumnya memahami bahasa adalah demikian, akan tetapi perkembangan zaman menjadikan bahasa ikut berkembang, apalagi bahasa politik. Manusia tidak bisa hanya berpijak pada arti bahasa yang pertama. Namun HTI menolak bersikap seperti itu. Akibat model pemahaman bahasa yang demikian, HTI menjadi rigid dan kaku, dan tanpa sadar telah men-taqdîs-kan makna demokrasi, dan akhirnya tidak berani memodifikasi. Demokrasi dibuat sedemikian rupa definisinya tanpa bisa diotak-atik. Arti demokrasi dinilai stagnan. Bahkan Hizbut Tahrir menandaskan, mengotak-atik makna demokrasi seperti hanya membatasi pada makna memilih penguasa adalah penyesatan sebagaimana yang dilakukan Amerika untuk menjajakan ide ini kepada kaum Muslim. ${ }^{74}$

Bagi kelompok ini, memaknai demokrasi harus dikembalikan kepada makna asal. Hafizh Shalih menjelaskan banyak orang merumuskan demokrasi sesuai dengan keyakinan atau akidah yang dipegang, kemudian dicocok-cocokkan, akhirnya makna demokrasi melenceng dari yang ditetapakan sejak awal mula istilah ini dibuat. ${ }^{75}$ Nampaknya, para aktivis Hizbut Tahrir ini mempunyai kemiripan dengan gaya Plato dan Aristoteles dalam menilai demokrasi. Plato mengatakan meskipun demokrasi itu mungkin diciptakan tapi tidak diinginkan. Demikian juga Aristoteles menyebut demokrasi sebagai model yang menyeleweng dan merosot. ${ }^{76}$

Lebih jauh, kalau dicermati pada masa sekarang ini bisa disaksikan bagaimana hebatnya pengaruh lingkungan, kebudayaan, kultural, dan ideologi terhadap makna bahasa, akhirnya ketika lingkungan dan

\footnotetext{
73 Taqî al-Dîn al-Nabhânî, Al-Shakhsîyah al-Islâmîyah, Vol. 3 (Beirut: Dâr al-Ummah, 2005), 127. Lihat juga Hịzb al-Tahrîr, Mîthâq al-Ummah (t.t.: Hịzb al-Tahrîr, t.th.), 32. ${ }^{74}$ Hizb al-Tạhrîr, Ajbizat Dawlat al-Khilâfah (Beirut: Dâr al-Ummah, 2005), 16.

75 Hafizh Shalih, Mengadili Demokrasi, terj. Yahya Abdurrahman (Bogor: Pustaka Thariqul Izzah, 2005), 1.

${ }^{76}$ Lihat catatan kaki karya Ainur Rofiq Al-Amin, Membongkar Proyek Khilafah ala Hiøbut Tahrir di Indonesia (Yogyakarta: LKiS, 2014), 72.
} 
budaya berubah, maka berubah juga makna bahasa itu. Walhasil bahasa menjadi sangat tergantung pada lingkungannya serta budayanya sebagaimana dijelaskan Azyumardi Azra, bahasa adalah cerminan pemahaman pemakai bahasa tentang kebudayaannya, masa silam dan masa sekarang. Perkembangan bahasa dipengaruhi perubahan sosio-budaya. ${ }^{77}$ Lebih dari itu, Komaruddin Hidayat menjelaskan bahwa bahasa juga bisa terkena polusi yang pada urutannya akan mendatangkan polusi dan penyakit pada sistem berfikir baik pada level individual maupun sosial. ${ }^{78}$ Penjelasan para pakar Muslim ini menegaskan bahwa bahasa bisa terpengaruh baik positif maupun negatif oleh faktor sosial dan budaya, tergantung siapa yang mampu mempengaruhinya.

Apalagi konsep demokrasi sendiri sebenarnya merupakan ide yang terus berkembang. Makna demokrasi berbeda sesuai dengan siapa yang menyuarakannya. Ahmad Syafi'i Maarif menjelaskan adanya istilah demokrasi terpimpin dalam masa Soekarno, demokrasi tanpa partai pada era Jamâl 'Abd al-Nâsir di Mesir, Kediktatoran demokratik era Sekou Toure, Demokrasi dasar masa Ayyub Khan, Demokrasi sejati zaman Castro, Republic of Democracy era Mao Zedong, semua ini adalah tidak lain sebagai perubahan konsep demokrasi, walau ternyata perubahan itu sekadar dijadikan jubah-jubah rekayasa untuk menutupi kediktatoran. $^{79}$

Hal di atas lebih dipertegas dalam buku Contemporary Political Ideologies Lyman Towers Sargent menjelaskan, demokrasi telah berkembang selama berabad-abad melalui modifikasi-modifikasi, baik dalam teori-teori khusus, maupun dalam praktik di sejumlah negara yang disebut demokratis. Terdapat berbagai perbedaan besar antara teori-teori dengan negara yang disebut demokratis, dengan sendirinya terdapat pula berbagai kata demokrasi tergantung pada kepercayaan politik si pembicara. ${ }^{80}$

Hal ini juga bisa dilihat dari analisis Mohtar Mas'oed bahwa demokrasi era tujuhpuluhan substantivis, rasional, utopian, dan ideal telah kehilangan banyak pengaruh. Teori demokrasi masa kini telah

\footnotetext{
77 Azyumardi Azra, Pergolakan Politik Islam (Jakarta: Paramadina, 1996), 232.

${ }^{78}$ Komaruddin Hidayat, Memahami Bahasa Agama: Sebuah Kajian Hermeneutik (Jakarta: Paramadina, 1996), 3.

79 Ahmad Syafi'i Maarif, Islam dan Politik: Teori Belah Bambu (Jakarta: Gema Insani Press, 1996), 198.

80 Lyman Tower Sargent, Contemporary Political Ideologies (Chicago, Illionis: The Dorsey Press, 1984), 33-32.
} 
berubah dan didominasi oleh teori Joseph Schumpeter yang berorientasi pada penekanan dan penciptaan prosedur. ${ }^{81}$ Adapun Robert Dahl berkomentar bahwa demokrasi yang difahami sekarang ini tidak sama dengan apa yang mungkin difahami orang Yunani di masa Pericles. ${ }^{82}$

Hal lain yang mendorong HTI bersikap kaku adalah kegagalan kelompok ini dalam menyerap perubahan dan perkembangan zaman, sehingga ide-ide ataupun peradaban yang merupakan hasil evolusi dan perkembangan zaman, tidak terkecuali yang datang dari Barat, tidak sedikit yang ditolak oleh HTI. Ini terbukti dengan konsep hạdârah dan madaniyah mereka. ${ }^{83}$ Tentu dalam hal ini demokrasi bagi HTI adalah badârah non-Islam yang harus ditolak.

\section{Negara Iran dan Mardomsalari}

Berbeda dengan HTI, model Islam politik yang diterapkan di Iran nampak lebih fleksibel dengan menyerap tren kemoderenan tanpa meninggalkan akar tradisi Islam. ${ }^{84}$ Model penyerapan demokrasi ala Iran adalah salah satu contoh yang bisa didiskusikan dan diapresiasi, tanpa harus terjebak kepada isu sektarian Sunnî-Shî‘ah yang sengaja dihembuskan pihak luar, maupun berusaha menduplikasi model ini ke dalam Republik Indonesia. Karena memang ada perbedaan antara Indonesia dengan Iran.

Iran sebagai pengemban salah satu model demokrasi faktanya negara ini adalah salah satu gudang ilmu-ilmu agama, sains, filsafat, sastra dan tasawuf. Demikian juga nilai-nilai islami yang sering dituntut oleh kelompok Islamis, juga mudah ditemukan dalam

81 Mohtar Mas'oed, Negara, Kapital, dan Demokrasi (Yogyakarta: Pustaka Pelajar, 1994), 8.

82 Robert A. Dahl, Demokrasi, dan Para Pengkritiknya, Vol. 1 (Jakarta: Yayasan Obor, 1992), xvii.

83 Hadârah adalah sekumpulan persepsi tentang kehidupan. Sedangkan madanîah adalah bentuk-bentuk fisik (benda) yang digunakan dalam aktivitas kehidupan. Lihat Taqî al-Dîn al-Nabhânî, Nizâm al-Islâm (Al-Quds: Hịizb al-Tahrîr, 2001), 63. Dalam buku Hịb al-Tahrîr yang lain juga dijelaskan bahwa hadârah yang datang dari selain Islam, baik itu hạâarah pada masa klasik seperti ḥậâab Persia, dan Romawi, maupun badârah pada era sekarang seperti kapitalisme, dan komunisme adalah ditolak. Hizb al-Tahrîr, Mîthâq al-Ummah (t.t.: Hịizb al-Tahrî̀, t.th.), 21.

${ }^{84}$ Setelah revolusi tahun 1979, Iran menyebut negaranya dengan Republik Islam Iran. Hizbut Tahrir tetap menolak model Republik Islam, karena sistem ini dianggap mengacu kepada sistem demokrasi. Lihat 'Abd al-Qadîm Zallûm, Niz̧âm al-Hụkm fi al-Islâm (Ttp: Hịizb al-Tahrî̀, 2002), 29, 31. 
kehidupan bermasyarakat dan bernegara di Iran. $^{85}$ Bahkan dalam bidang sains, Iran cukup membanggakan dunia Muslim karena laporan Royal Society pada tahun 2011 menyebut Iran sebagai nagara yang paling cepat perkembangan sainsnya, "the fastest growing country for science" ${ }^{86}$

Iran tidak alergi terhadap demokrasi, tapi bersikap kritis. Dalam suatu peristiwa, negara Mullah ini mengecam negara Barat yang memanipulasi demokrasi untuk memaksimalkan kepentingan mereka. Iran menuding selama ini Barat memanipulasi konsep Hak Asasi Manusia dan demokrasi untuk mencapai tujuan politiknya. Barat kerap membicarakan mengenai HAM. Tapi diam saat terjadi banyak pembunuhan rakyat Palestina dan Bahrain. Di mana pun insiden teroris, jejak-jejak intelijen Barat dapat ditelusuri. Selama ini Barat (AS) kerap menyalahgunakan konsep demokrasi. ${ }^{87}$

85 Menurut Dina Y. Suleman yang pernah tinggal di Iran 1999-2007, dan pernah menulis buku Abmadinejad on Palestine, Journey to Iran: A Note from Tehran bahwa di Iran hukum Islam diterapkan dengan penegakan undang-undang yang disusun berdasarkan sharî'at Islam oleh parlemen yang anggotanya dipilih melalui pemilu. Setelah RUU dibuat, akan diverifikasi oleh Dewan Pakar (Syra-e Negabban) yang beranggotakan para pakar bidang hukum, dan fiqh untuk meneliti apakah sudah bersesuaian dengan sharî‘at Islam. Bila masih ada yang kurang cocok menurut sharî‘at Islam, RUU tersebut dikembalikan lagi ke parlemen untuk direvisi. Salah satu penerapan model kehidupan bermasyarakat, dan bernegara di Iran adalah tuntutan zaman seperti dalam hal emansipasi perempuan. UU Iran mempersilakan perempuan berkarir di berbagai bidang, tetapi perusahaan yang memiliki pegawai perempuan harus memfasilitasi mereka agar mampu menjalankan perannya dalam keluarga. Tempat kerja harus memberikan setengah jam dalam setiap tiga jam kepada perempuan untuk menyusui anaknya sampai si anak berusia dua tahun, dan setengah jam cuti itu harus dihitung sebagai jam kerja. Demikian juga masalah hijab, di Iran, semua perempuan usia baligh wajib berjilbab (apapun agamanya, termasuk turis asing yang datang ke Iran). Namun ini tidak membuat gerak perempuan terbatas karena jilbab diakomodasi dalam seluruh sistem kehidupan. Misalnya perempuan yang ingin berenang atau bermain sepakbola pun tetap bisa berjilbab karena disediakan sarana khusus kolam renang atau stadion olahraga untuk perempuan. Berbagai profesi tetap bisa dilakukan oleh perempuan Iran dengan hijabnya, bahkan untuk pekerjaan maskulin, semisal menjadi polisi, tentara, sopir bus atau taksi. Demikian pula masalah bank yang sistemnya islami, tidak mengenal riba, dan tidak mengikatkan diri pada Bank Sentral Amerika atau Inggris.

86 Husain Heriyanto, Revolusi Saintifik Iran (Jakarta: UI Press, 2013), 11, 13, 205. Untuk masalah kontribusi Iran dalam peradaban Islam, lihat Ghulam Reza Awani (ed.), Islam, Iran \& Peradaban (Yogyakarta: Rausyan Fikr, 2012).

87 Tim Redaksi Republika, "Iran: AS Manipulasi Demokrasi untuk Kepentingan Sendiri”, dalam http://www.republika.co.id/berita/ internasional/timur-tengah/0508-2012/ (6 Januari 2013). 
Sekalipun Iran mengritik praktik demokrasi Barat, namun negara ini menerima sisi-sisi konsep demokrasi secara kritis dan tentu berupaya ditarik ke akar Islam. Jenis sistem politik Iran bukan benarbenar teokratis, di mana orang tidak memiliki keterlibatan langsung dalam politik mereka, maupun demokrasi murni, di mana kehendak rakyat adalah faktor penentu yang mampu mengubah struktur politik seluruh negara. Sistem politik Iran adalah kombinasi dari berbagai jenis sistem politik, terutama kombinasi dari demokrasi dan teokrasi, dan tentu saja dalam kasus tertentu sangat berbeda dengan kedua model tersebut. ${ }^{88}$ Khalid al-Walid menyebut pemerintahan Iran sebagai konsep pemerintahan teodemokrasi. ${ }^{89}$ Model demokrasi ala Iran ini tidak ada di negara-negara Muslim lainnya seperti Arab Saudi, Yordania, Maroko, Kuwait, dan seterusnya dan bahkan Mesir, Suriah, Tunisia, Libya dan sebagainya, maupun dalam demokrasi barat seperti Inggris, Perancis, Italia, Amerika Serikat dan sebagainya..$^{90}$

Para pakar Islam sering menyebut demokrasi Iran sebagai aldîmuqrâtîyah al-dînîyah (religious democracy/religious mardomsalari). Mardomsalari (bahasa Persi untuk demokrasi) yang religius adalah sistem yang tegak pada masyarakat religius setelah mereka menerima kepemimpinan agama atas kehidupan sosial dan politiknya. ${ }^{91}$ Religious mardomsalari negara Iran terlihat dari pengakuan atas kedaulatan Tuhan dan keterlibatan rakyat dalam mengatur administrasi negara seperti pada pasal 6 dan 56 UUD Iran. ${ }^{92}$

Mohammad Bagher Khorramshad menjelaskan tentang demokrasi religius adalah model sistem Islam yang konsisten dengan

\footnotetext{
${ }^{88}$ Bahram Nawazeni, "Religious Democracy, and Theocracy", dalam Ajaz Hussain (ed.), Religious Democracy (Tehran: Alhoda International Cultural, 2012), 212-213.

${ }^{89}$ Khalid Al-Walid, "Wilayatul Faqih: Konsep Pemerintahan Teodemokrasi", Jurnal Review Politik, Vol. 3, No. 1 (Pebruari 2013), 102-110. Dalam penelusuran penulis, tokoh yang membuat nomenklatur teodemokrasi adalah Abû al-A'lâ al-Mawdûdî. Lihat Abû al-A'lâ al-Mawdûdî, Sistem Politik Islam, terj. Asep Hikmat (Bandung: Mizan, 1995), 159-160.

${ }^{90}$ Mohammad Bagher Khorramshad, "Prelude", dalam Ajaz Hussain (ed.), Religious Democracy (Tehran: Alhoda International Cultural, 2012), 17.

91 Mas'ûd Ikhwan Kâdhimî, "Makânah wa Dawr al-Qiyâdah al-Dîmuqratîyah alDînîyah wa Muqâranah dhâlik bi al-Dîmuqratîyah al-Gharbîyah", dalam Shâkir Kisrâi, dan 'Abdul Mahdi Bâzarkâni (ed.), Al-Dîmuqratîyah al-Dînîyah (Teheran: Muassasah Alhuda, 2012), 31.

${ }^{92}$ Khorramshad, "Prelude", 14-15.
} 
definisi demokrasi minimalis, dan definisi agama maksimalis. ${ }^{93}$ Demokrasi minimalis adalah sebagaimana yang dikutip oleh John Stuart Mill ada tiga syarat esensial demokrasi yang berupa hak publik untuk memilih, pilihan yang bebas, dan pemungutan suara secara rahasia. Sedang demokrasi maksimalis adalah sebagaimana dipresentasikan oleh John Locke kebebasan dan kesetaraan natural manusia, hak untuk hidup dan kepemilikan, syarat-syarat dan batasanbatasan bagi pemerintah yang ditetapkan oleh hukum alam dan publik, pengabaian keberagamaan, pemisahan kekuasaan pemerintahan, mengutamakan masyarakat sebelum pemerintah, dan hak untuk bangkit melawan penguasa despotik. ${ }^{94}$

Selanjutnya Khorramshad menjelaskan arti agama minimalis adalah kepercayaan yang bersifat personal, yang hanya kembali kepada relasi antara manusia dan Tuhan. Relasi ini berkaitan dengan akhirat, pahala, dan hukuman. Dalam definisi ini tidak ada misi sosial dan alam. Sedangkan arti agama maksimalis Islam sebagai seperangkat aturan yang jelas yang berfungsi sebagai way of life dan cara untuk menuju kesempurnaan. Hal ini membawa ideologi Islam sebagai realitas yang ada dalam kehidupan manusia sebagai akar moral dan basis fundamental serta kekuatan dalam masyarakat, demikian juga sebagai organisasi politik, sistem sosial, sistem ekonomi, hukum internasional dan solidaritas global. ${ }^{95}$

Dalam demokrasi religius, tujuan pemerintah menjamin pertumbuhan manusia menuju nilai-nilai Ilahi. ${ }^{96}$ Bagi calon pemimpin Iran juga harus dipilih dari mereka yang mendekati nilai-nilai ilahi. Lebih detail, sifat dan syarat yang harus dipenuhi oleh seorang pemimpin di dalam sistem demokrasi religius di Iran tercermin dari tiga hal, yakni pertama, kekhususan dalam hal akhlaq (adil, takwa, dan berani seperti pada konstitusi Iran pasal 5). Kedua, kekhususan dalam hal agama (faqîh atau âlim dan mampu untuk memberi fatwa seperti pada pasal 5 dan 109). Ketiga, kekhususan yang berkaitan kafấah atau kemampuan untuk memahami perubahan zaman, berani, ahli manajemen (pasal 5). ${ }^{97}$ Pemimpin tertinggi dalam demokrasi Iran

\footnotetext{
93 Mohammad Bagher Khorramshad, "Religious Democracy: The Democracy of the Righteous", dalam Ajaz Hussain (ed.), Religious Democracy (Tehran: Alhoda International Cultural, 2012), 290.

94 Ibid., 256, 259.

${ }^{95}$ Ibid., 266, 267, 268.

${ }^{96}$ Ibid., 280.

${ }^{97}$ Kâdhimî, "Makânah wa Dawr al-Qiyâdah", 35.
} 
disebut dengan wali faqîh yang akan menjaga sistem Islam negara tersebut. ${ }^{98}$ Adapun yang menjaga wali faqîh dari tindakan yang absolut dari dari penyimpangan, dibentuklah majelis faqîh yang terdiri dari para marjâ' al-taqlid dan majelis kbubregon, sebuah majelis yang berisi para ulama dan cendekiawan yang bertugas memilih dan mengawasi kinerja dan kebijakan walî faquî. ${ }^{99}$

Inilah titik temu dan titik beda antara demokrasi dan wilâyah alfaqîh. Titik bedanya wilâyah al-faqîh berkarakter religius dan menganut kedaulatan Tuhan, sedangkan demokrasi berkarakter materialistik dan menganut kedaulatan rakyat. Adapun titik temunya, sama-sama mengakui hak politik rakyat. ${ }^{100}$

Salah satu contoh praktisnya adalah calon pemimpin Iran (presiden) ketika mau mencalonkan diri, mereka harus mendapat asesmen atau penilaian dari walî faqîh dengan dewan pakarnya. Setelah lolos dari penilaian walî faqîh, calon presiden bisa mengikuti kontestasi lewat pemilihan umum yang akan dipilih oleh rakyat. Dari sini dapat dipahami, rakyat tetap terlibat, bahkan sebagai penentu akhir terpilih tidaknya seseorang untuk menjadi presiden, namun tentu setelah ada proses seleksi dari wali faqîh.

Bagi rakyat Iran, pemilu bukan sekadar hak, namun lebih dari itu, mereka memandang hal ini sebagai ibadah dan kewajiban Ilahi. Melalui pemilu, mereka akan memilih kandidat yang paling saleh untuk diberi kepercayaan menjalankan roda pemerintahan dan undang-undang negara. Dengan demikian kehormatan agama dan bangsa semakin kokoh. ${ }^{101}$ Dengan konsep demokrasi religius yang demikian, maka apa yang dikatakan HTI sulit terjadi. HTI mengatakan bahwa demokrasi dengan one-man one-vote memaksa para pelakunya untuk menggunakan logika jumlah. Dalam waktu pendek, tidak mudah meraih jumlah pendukung yang signifikan. Paling gampang adalah dengan menjual "sesuatu" yang diterima oleh massa. ${ }^{102}$

\footnotetext{
98 Ghadanfar Ruknun Âbâdî, Al-Islâm wa al-Nizâam al-Siyâsî fî al-Jumbûrîyah al-Islâmîyah al-Îrânîyah (Beirut: Markaz al-Ḥaḍârah li Tanmîyah al-Fikr al-Islâmî, 2011), 432.

99 Al-Walid, "Wilayatul Faqih", 109.

100 Muhammad Anis, Islam, dan Demokrasi: Perspektif Wilayah Al-Faqih (Jakarta: Mizan, 2013), 223.

101 Tim Redaksi IRIB Indonesia, "Pemilu dalam Perspektif Demokrasi Agama", dalam http://indonesian.irib.ir/sosialita/ (18 Mei 2013).

102 Tim Redaksi Hizbut Tahrir Indonesia, “Jebakan Demokrasi”, dalam http:// hizbut-tahrir.or.id/04-03-2013/ (18 April 2013).
} 
Demikian pula tuduhan aktivis HTI terhadap demokrasi Iran menjadi emosional dan tidak bermakna. Fathiy Syamsuddin Ramadhan An Nawiy alias Suryo menulis artikel dengan judul provokatif, "Menyingkap Selubung Kejahatan Rezim Taqiyyah: "Kebodohan paling Bodoh adalah Percaya kepada Orang yang Menganut Taqiyyah". Salah satu poin tulisannya adalah menjelaskan bukti persekongkolan licik dan jahat antara Khomeini dan AS bisa dilihat dari konstitusi Iran, yang menjadikan Iran sebagaimana negeri Republik Iran yang menerapkan prinsip-prinsip demokrasi. Demikian juga tampak kedangkalan penjelasan Utsman Bakhasy, direktur central-media office Hizbut Tahrir bahwa sistem pemerintahah Iran diadaptasi dari sistem pemerintahan Barat buatan manusia. Di dalam Islam tidak ada konsepsi republik islami. Sistem pemerintahan Iran tegak di atas republik dan dalam batas-batas nasionalisme Iran. Semua itu bertentangan dengan Islam. ${ }^{103}$

Akhirnya ada benarnya penegasan Ahmad Vaezi bahwa orang yang menolak demokrasi semisal beralasan dengan ayat "siapa yang mencari agama selain Islam, maka tidak akan bisa diterima diterima" (Q.S. Âli Imrân [3]: 85), ataupun berdalih dengan Q.S. al-Nisâ’ [4]: 59 yang artinya "orang seperti ini mempunyai pandangan yang picik dan tidak bisa melihat realitas ragam model dan interpretasi tentang demokrasi”. ${ }^{104}$

\section{Penutup}

Menurut HTI, demokrasi adalah realitas yang menghasilkan dampak negatif baik dalam sistem politik dan pemerintahan, serta dalam berbagai sendi kehidupan rakyat dan umat Islam, mulai dari ekonomi, sosial, pendidikan, dan akhlak, bahkan terorisme.

Sedangkan bangunan pemikiran HTI untuk menolak demokrasi dapat disimpulkan dengan lima alasan: pertama, demokrasi adalah ciptaan akal manusia yang sama sekali tidak ada kaitannya dengan wahyu dan agama samawi. Kedua, demokrasi muncul dari ideologi sekularisme berupa pemisahan agama dari kehidupan yang pada gilirannya pemisahan agama dari negara. Ketiga, demokrasi berpijak dari kedaulatan di tangan rakyat, dan rakyat sumber kekuasaan.

103 Tim Redaksi Hizbut Tahrir Indonesia, "Utsman Bakhasy, Direktur Central Media Office Hizbut Tahrir: Iran Setia Melayani AS", dalam http://hizbuttahrir.or.id/06-01-2013/ (7 Maret 2013).

104 Ahmad Va'ezi, "Theocratic Democracy and Its Critics", dalam Ajaz Hussain (ed.), Religious Democracy (Tehran: Alhoda International Cultural, 2012), 32. 36. 
Keempat, demokrasi berpijak kepada hukum mayoritas. Kelima, demokrasi mengembangkan ide kebebasan seperti kebebasan berakidah, kebebasan berpendapat, kebebasan kepemilikan, dan kebebasan personal. Semua ide demokrasi ini menurut HTI secara diametral bertentangan dengan sharî‘ at Islam.

Penolakan HTI terhadap demokasi diakibatkan model pemahaman yang rigit dan kaku yang tanpa sadar kelompok ini telah mentaqdiskan atau menyakralkan makna demokrasi tanpa berani memodifikasi. Demokrasi dibuat sedemikian rupa definisinya tanpa bisa diotak-atik. Arti demokrasi dinilai stagnan tanpa ada perubahan. Bagi HTI, memaknai demokrasi harus dikembalikan kepada makna asal.

Dalam Islam politik, hendaknya bersikap fleksibel dengan menyerap perkembangan dan tren kemoderenan, tanpa meninggalkan akar tradisi Islam (al-mubâfazah 'alâ al-qadîm al-sâlih, wa al-akbdh bi aljadìd al-aslab.). Sikap seperti ini diperlukan untuk mengakomodir dan mengantisipasi perkembangan zaman. Dalam hal ini, ada contoh seperti yang dikenalkan Republik Islam Iran yang memasukkan aldîmuqrâtîyah al-dinîyah (religious democracy atau religious mardomsalari) ke dalam sistem politik Islamnya yang sering disebut dengan wilâyat alfaqîh. Karena HTI bersikap kaku, konsekuensi politiknya kelompok ini akan sulit mengakomodasi dan mengantisipasi perkembangan dan perubahan konstalasi politik global. Bahkan kalau tidak segera disadari akan mirip dengan apa yang dilakukan Taliban.

\section{Daftar Rujukan}

Âbâdî, Ghadanfar Ruknun. Al-Islâm wa al-Niz̧âm al-Siyâsî fì alJumbûrîyah al-Islâmîyah al-Îrânîyah. Beirut: Markaz al-Hạạârah li Tanmîyah al-Fikr al-Islâmî, 2011.

Abdurrahman, Yahya. "Biografi Singkat Pendiri Hizbut Tahrir Syaikh Taqiyuddin an-Nabhani", Al-Wa'ie, No. 55 tahun V, Maret 2005.

Al-Amin, Ainur Rofiq. Membongkar Proyek Khilafah ala Hizbut Tabrir di Indonesia. Yogyakarta: LKiS, 2014.

Al-Wa'ie, Tim Redaksi. “'Atha Abu Ar-Rasythah, Amir Hizbut Tahrir Saat Ini”, Al-Wa'ie, No. 77 tahun VII, Januari 2007.

----. Tim Redaksi. "Meneropong Hizbut Tahrir bagian 1", Al-Wa'ie, No. 77 tahun VII, Januari 2007.

----. "Mengenal Syaikh Taqiyuddin an-Nabhani, Pendiri Hizbut Tahrir", Al-Wa'ie, No. 74 tahun VII, Oktober 2006. 
-----. "Krisis Palestina, dan Relevansi Khilafah", Al-Waie, No. 72 tahun VI, Agustus, 2006.

----. "Akhbar Al-Waie", Al-Wa'ie, No. 73 tahun VII, September 2006.

Al-Walid, Khalid. "Wilayatul Faqih: Konsep Pemerintahan Teodemokrasi”, Jurnal Review Politik, Vol. 3, No. 1, Pebruari 2013.

Amhar, Fahmi. "Hanya Khilafah Islam yang Mampu Melawan AS", Al-Waie, No. 53 tahun V, Januari 2005.

Anis, Muhammad. Islam, dan Demokrasi: Perspektif Wilayah Al-Faqih. Jakarta: Mizan, 2013.

Awani, Ghulam Reza (ed.). Islam, Iran \& Peradaban. Yogyakarta: Rausyan Fikr, 2012.

Azra, Azyumardi. Pergolakan Politik Islam. Jakarta: Paramadina, 1996.

Chaidaroh, Umi. "Fikih Perempuan Hịb al-Tahrî̀". Disertasi--IAIN Sunan Ampel, Surabaya, 2011.

Dahl, Robert A. Demokrasi, dan Para Pengkritiknya, Vol. 1. Jakarta: Yayasan Obor, 1992.

Heriyanto, Husain. Revolusi Saintifik Iran. Jakarta: UI Press, 2013.

Hidayat, Komaruddin. Memahami Bahasa Agama: Sebuab Kajian Hermeneutik. Jakarta: Paramadina, 1996.

Hilmy, Masdar. Islam sebagai Realitas Terkonstruksi. Yogyakarta: Kanisius, 2009.

Hizbut Tahrir Indonesia, Tim Redaksi. "Bukan Golput, tapi Demokrasi yang Beri Peluang Kafir Berkuasa", dalam http://hizbuttahrir.or.id/07-04-2012/, 8 April 2013.

----. "Bukti Standar Ganda, Muslim Belanda Didenda Karena Buat Kartun Holocaust", dalam http://hizbut-tahrir.or.id/21-082010/, 6 November 2012.

----. "Demokrasi Bertentangan dengan Islam, Harus Dicampakkan!", dalam http://hizbut-tahrir.or.id/29-05-2013/, 24 Mei 2013.

----. "Demokrasi Biang Kerok Terorisme", dalam http://hizbuttahrir.or.id/30-01-2013/, 24 Mei 2013.

----. "Demokrasi bukan Sistem yang Kondusif", dalam http:/ / hizbut-tahrir.or.id/27-03-2013/, 24 Juni 2013.

----. "Demokrasi Ciptakan Pemerintah Sableng", dalam http:// hizbut-tahrir.or.id/13-05-2013/, 16 Juni 2013. 
-----. "Demokrasi dan Nasionalisme Kufur dan Beracun", dalam http:/ / hizbut-tahrir.or.id/09-02-2013/, 6 Maret 2013.

. "Demokrasi Liberal Amerika Adalah Permainan, Sesungguhnya Amerika Adalah Negara Totaliter", dalam http://hizbut-tahrir.or. id/12-11-2012/, 13 Januari 2013.

-----. "Demokrasi Mengorbankan Perempuan", dalam http://hizbuttahrir.or.id/04-03-2013/, 25 Mei 2013.

----. "Demokrasi Sistem Gagal dan Merusak", dalam http://hizbuttahrir.or.id/15-05-2013/, 5 Mei 2013.

----. "Foto: Kerusakan Produk UU dalam Sistem Demokrasi", dalam http://hizbut-tahrir.or.id/27-04-2013/, 16 Mei 2013.

----. "Haruskah HTI Berterima Kasih kepada Demokrasi", http://hizbut-tahrir.or.id/04-08-2011/, 31 Juni 2013.

-----. "HTI Ajak Warga Jatim Tinggalkan Demokrasi”, dalam http://hizbut-tahrir.or.id/26-05-2013/, 24 Juni 2013.

----. "Ironi Demokrasi Buruk, Tapi Laku", dalam http://hizbuttahrir.or.id/25-05-2013/, 16 Juli 2013.

----. "Jawab Soal tentang Demokrasi”, dalam http://hizbuttahrir.or.id/08-06-2013/, 5 Juli 2013.

----. "Jebakan Demokrasi”, dalam http://hizbut-tahrir.or.id/04-032013/, 18 April 2013.

----. "Jelang Pemilu Ratusan Ulama Jatim Serukan Tolak Demokrasi”, dalam http://hizbut-tahrir.or.id/09-03-2012/, 18 Maret 2013.

----. "Menolak Jalan Demokrasi”, dalam http://hizbuttahrir.or.id/30-01-2013/, 6 Maret 2013.

----. "Pendidik tak Berakhlak Buah Penerapan Sistem Kapitalisme Demokrasi”, dalam http://hizbut-tahrir.or.id/24-04-2013/, 6 Mei 2013.

-----. "Pengajian Masjid ar-Ridlo Pertegas Demokrasi Biang Korupsi”, dalam http://hizbut-tahrir.or.id/06-04-2013/, 6 Mei 2013.

-----. "Pengusung Demokrasi Takut Ekstra Parlemen Meninggi", dalam http://hizbut-tahrir.or.id/28-01-2013/, 24 Juni 2013.

----. "Penolakan terhadap Ajang Pamer Aurat Miss World Bukti Keimanan Seorang Muslim", dalam http://hizbut-tahrir.or.id/3101-2013/, 16 Maret 2013. 
-----. "Pernyataan HTI Tolak Penyelenggaraan Miss World 2013 di Indonesia", dalam http://hizbut-tahrir.or.id/30-03-2013/, 26 Juni 2013.

-----. "Political Outlook 2014: Selama Masih Demokrasi, 2014 Tetap Krisis!", dalam http://hizbut-tahrir.or.id/19-01-2013/, 18 Maret 2013.

----. "Rokhmat S. Labib: Mengajak pada Demokrasi Sama dengan Mengajak pada Jahannam”, dalam http://hizbut-tahrir.or.id/2602-2013/, 5 Maret 2013.

-----. "Saresehan Intelektual: Ilusi Intelektual Cerdas Bertakwa dalam Sistem Demokrasi", dalam http://hizbut-tahrir.or.id/20-052013/, 5 Juni 2013.

-----. "Syura: Demokrasi Tidak Sama dengan Islam", dalam http:// hizbut-tahrir.or.id/04-03-2013/, 6 Mei 2013.

-----. “Tentang Kami”, dalam http://hizbut-tahrir.or.id/, 8 April 2012.

----. "The End of Democracy", dalam http://hizbut-tahrir.or.id/0705-2013/, 24 Juni 2013.

----. "Utsman Bakhasy, Direktur Central Media Office Hizbut Tahrir: Iran Setia Melayani AS", dalam http://hizbut-tahrir.or.id/06-012013/, 7 Maret 2013.

-----. "Yang Menolak Syariah Islam Justru Mengidap Hipocracy Democracy", dalam http://hizbut-tahrir.or.id/21-07-2013/, 5 Agustus 2013.

-----. "Muslimah HTI Serukan Tinggalkan Demokrasi", dalam http://hizbut-tahrir.or.id/17-03-2013/, 18 Mei 2013.

HTI, Muslimah. Kelemahan Sistem Demokrasi dalam Melindungi Anak dari Pornografi dan Seks Bebas. Jakarta: Muslimah HTI, 2010.

Indonesia, Hizbut Tahrir. Manifesto Hizbut Tabrir untuk Indonesia. Jakarta: Hizbut Tahrir Indonesia, 2009.

IRIB Indonesia, Tim Redaksi. "Pemilu dalam Perspektif Demokrasi Agama" dalam http://indonesian.irib.ir/sosialita/Diakses 18 Mei 2013.

Khâlidî (al), Maḥmûd 'Abd al-Majîd. Qawâid Nizâam al-Hukem fî al-Islâm. Beirut: Dâr al-Buhûth al-'Ilmîyah, 1980.

Khilafah Magazine Supplement, International Muslim Khilafah, London, Inggris, Agustus 1994. 
Khorramshad, Mohammad Bagher. "Prelude", dalam Ajaz Hussain (ed.), Religious Democracy. Tehran: Alhoda International Cultural, 2012.

-----. "Religious Democracy: The Democracy of the Righteous", dalam Ajaz Hussain (ed.), Religious Democracy. Tehran: Alhoda International Cultural, 2012.

K-Mag, Editor. "Menggugat Mitos Kebebasan Berbicara", Khilafah Magazine, No. 7 tahun I, April 2006.

K-Mag, Editor. "Pernyataan Dusta Mengatasnamakan Kebebasan", Khilafah Magazine, No. 7 tahun I, April 2006.

Labib, Rokhmat S. "Syura Bukan Demokrasi", Al-Wa'ie, No. 104 tahun IX, April 2009.

Maarif, Ahmad Syafi'i. Islam, dan Politik: Teori Belah Bambu. Jakarta: Gema Insani Press, 1996.

Mas'ûd Ikhwan Kâdhimî, "Makânah wa Dawr al-Qiyâdah alDimuqratîyah al-Dînîyah wa Muqâranah dhâlik bi alDîmuqratîyah al-Gharbîyah", dalam Shâkir Kisrâi, dan 'Abdul Mahdi Bâzarkâni (ed.), Al-Dimuqratîyah al-Dînyyah. Teheran: Muassasah Alhuda, 2012.

Mawdûdî (al), Abû al-A'lâ. Sistem Politik Islam, terj. Asep Hikmat. Bandung: Mizan, 1995.

Mas'oed, Mohtar. Negara, Kapital, dan Demokrasi. Yogyakarta: Pustaka Pelajar, 1994.

Musa, Lathifah. "Demokrasi Menghinakan Perempuan", Al-Wa'ie, No. 104 tahun IX, April 2009.

Nabhânî (al), Taqî al-Dîn. Al-Shakhsîyah al-Islâmîyah, Vol. 3. Beirut: Dâr al-Ummah, 2003.

----- al-Takattul al-Hịiz̧b̂̀. Al-Quds: Hịb al-Taḥîr, 2000.

----- Nižâm al-Islâm. Al-Quds: Hịib al-Tahrîr, 2001.

Nawazeni, Bahram. "Religious Democracy, and Theocracy," dalam Ajaz Hussain (ed.), Religious Democracy. Tehran: Alhoda International Cultural, 2012.

Republika, Tim Redaksi. "Iran: AS Manipulasi Demokrasi untuk Kepentingan Sendiri” dalam http://www.republika.co.id/berita/ internasional/timur-tengah/05-08-2012/Diakses 6 Januari 2013.

Sargent, Lyman Tower. Contemporary Political Ideologies. Chicago, Illionis: The Dorsey Press, 1984. 
Shalih, Hafizh. Mengadili Demokrasi, terj. Yahya Abdurrahman. Bogor: Pustaka Thariqul Izzah, 2005.

Tahrîr (al), Hiizb. Ajhizat Dawlat al-Khilâfah. Beirut: Dâr al-Ummah, 2005.

----. Hį̧ al-Tahrrîr. Beirut: Dâr al-Ummah, 2010.

----. Mafâbîm Hį̧b al-Taḅrîr. Al-Quds: Hið̧b al-Tạ̣rî, 2001.

----. Manhaj Hį̧b al-Tạ̣rîr fî al-Taghyîr. Beirut: Hizb al-Tahrîr, 2009.

----. Mîthâq al-Ummah. t.t.: Hizb al-Tahrî̀, t.th.

Uwik, Gus. "Demokrasi, dan Kebohongan Publik", Al-Wa'ie, No. 21 tahun II, Mei 2002.

Va'ezi, Ahmad. "Theocratic Democracy, and its Critics", dalam Ajaz Hussain (ed.), Religious Democracy. Tehran: Alhoda International Cultural, 2012.

Victoria, Adi. "Perubahan Hakiki Bukan dari Pemilu", dalam http:/ /hizbut-tahrir. or.id /27-03-2013/ Diakses 8 April 2013.

Wajdi, Farid. "Demokrasi Sistem Kufur", Al-Wa'ie, No. 104, tahun IX, April 2009.

Yusanto, Muhammad Ismail. "Dalam Demokrasi, Siapapun Cenderung Jadi Buruk" dalam http://hizbut-tahrir.or.id/27-022013/Diakses 24 Mei 2013.

Zallûm, 'Abd al-Qadîm. Al-Dimuqrạtîyah Nizâam al-Kufr, Yạ̣rum Akbdhubâ aw Tatbíquhâ aw al-Da'wah Ilayhâ. t.t.: Hizb al-Tahrîr, t.th.

-----. Niz̧âm al-Ḥukm fì al-Islâm. t.t.: Hịzb al-Tahrî̀, 2002. 